\title{
Evaluation of physiological traits in upland rice for adaptation to no-tillage system
}

\author{
Alexandre B. Heinemann ${ }^{1 *}$; Luís Fernando Stone ${ }^{1}$; Nand K.Fageria ${ }^{1}$ and Lucas M. de Castro ${ }^{2}$ \\ ${ }^{1}$ Pesquisador Embrapa Arroz e Feijão, Rodovia G0-462 km 12 Zona Rural 75375-000 Santo Antônio de Goiás, G0. \\ ${ }^{2}$ Estudante de graduação do curso de agronomia da Universidade Federal de Goiás, Campus Samambaia. \\ * Corresponding author: Tel. +55 623533 2153; alexbh@cnpaf.embrapa.br. \\ Received: 14 April 2009; Accepted: 19 October 2009
}

\begin{abstract}
In the cerrado region of Brazil, no-tillage is an alternative management practice to conserve soil and reduce cost of crop production. However, many studies have been showed that there is a decrease in the yield when upland rice is cropped in this system. Therefore, there is a need that new breeding initiatives introgress favorable traits into upland rice for no-tillage adaptation. Key traits include faster emergence, ability to germinate when deep seeded, faster root development, and early canopy closure during the vegetative stages. All those traits can be summarized as "early vigor". So, the objective of this study was to evaluate physiological traits of four contrasting parental upland rice cultivars to verify their adaptation to no-tillage system. A greenhouse experiment with four upland rice cultivars (BRS Primavera, BRS Curinga, BRS Soberana, and Douradão) were planted at three different dates and growth at potential conditions. Development stages, total dry matter, leaf area, leaf dry matter, leaf length, leaf elongation rate and leaf duration were measured and calculated. Based on physiological traits, the four cultivars showed differences in the growth cycle. However, for biomass and leaf area growth and leaf expansion traits they did not differ significantly, probably being the lack of genetic "early vigor" a characteristic of the modern cultivars. The growth and development pattern was significantly affected by planting dates and not by cultivars.
\end{abstract}

Key words: Leaf area, leaf expansion, Oryza sativa L, shoot dry weight.

\section{AVALIAÇÃO DE CARACTERÍSTICAS FISIOLÓGICAS DO ARROZ DE TERRAS ALTAS PARA ADAPTAÇÃO AO SISTEMA DE PLANTIO DIRETO.}

Resumo - Na região dos Cerrados brasileiros, o plantio direto é uma prática alternativa de manejo que visa a conservação do solo e redução dos custos de produção. Entretanto, muitos estudos sinalizam que há redução na produtividade quando 0 arroz de terras altas é cultivado nesse sistema. Portanto, há necessidade que as novas iniciativas do melhoramento contemplem a introgressão de características favoráveis à adaptação do arroz ao plantio direto. Essas características incluem mais rápida emergência, habilidade para germinar quando semeado profundo, mais rápido desenvolvimento radicular, e fechamento do dossel mais cedo durante os estádios vegetativos. Todas essas características podem ser resumidas como "vigor inicial". Um experimento em casa de vegetação com quatro cultivares de arroz de terras altas (BRS Primavera, BRS Curinga, BRS Soberana e Douradão) foi semeado em três diferentes datas e cultivado em condições potenciais de crescimento. Os estádios de desenvolvimento, matéria seca acumulada, área foliar, comprimento das folhas do colmo principal, taxa de elongação e duração das folhas foram medidos e calculados. Baseado nas informações fisiológicas obtidas, os quatro cultivares mostraram diferenças no ciclo de desenvolvimento. Entretanto, para a biomassa acumulada, área foliar e características relacionadas à expansão das folhas eles não diferiram significativamente. 
Assim, a não presença de um "vigor inicial" genético pode ser uma característica ganética dos cultivares modernos. Os padrões de crescimento e desenvolvimento foram significativamente afetados pelas datas de semeadura e não pelo cultivar.

Palavras-chaves: área foliar, expansão de folhas, Oryza sativa L, matéria seca acumulada.

\section{INTRODUCTION}

Rice is mainly grown under two ecosystems known as upland and lowland. Upland rice is an important crop in South America cropping systems. Rice grown in rain-fed, naturally well-drained soils, without surface water accumulation, normally without water table supply, and normally not bounded is called upland rice (Fageria, 2001). Average yield of upland rice in Brazil is about $2 \mathrm{Mg} \mathrm{ha}^{-1}$, whereas, average yield of lowland rice is about $5 \mathrm{Mg} \mathrm{ha}^{-1}$ (IBGE, 2006). Approximately the same situation occurs in other upland rice producing regions of the world (Fageria, 2001). The low yield of upland rice is due to unstable environmental factors and use of low technology by the farmers. In Brazil, upland rice is mostly grown in the central part locally known as "cerrado" region. Most of the soils of the cerrado region are Oxisols and Ultisols. They are infertile and acidic in reaction. With the use of adequate rate of lime and fertilizers, upland rice grown in cerrado region have produced good yields under conventional tillage (Fageria and Baligar, 2001; 2003).

In the cerrado region of Brazil, conservation or notillage is emerging as an alternative management practice to conserve soil and reduce cost of crop production (Bolliger et al., 2006). Forty-five percent of total cultivated land in Brazil is now estimated to be managed with zero-tillage, although in southern Brazil, this figure is reported to exceed $80 \%$ (Amado et al., 2006; Bolliger et al., 2006). Many studies have been showed that there is a decrease in the yield when upland rice is cropped in no or reduced tillage system (Reis et al., 2007; Moura et al., 2002). Therefore, there is a need that new breeding initiatives introgress favorable traits into upland rice in areas where reduced or no-tillage is being adopted. Key traits include faster emergence, ability to germinate when deep seeded (so that crops compete with weeds and use available moisture more efficiently), faster root development to enable rapid establishment of the crop (Trethowan and Reynolds, 2005) and early canopy closure during the vegetative stages. All those traits can be summarized as "early vigor". In this scenario, fast expansion of leaves in upland rice can play an important role for finding the appropriate plant ideotype for no-tillage crop system. Leaf expansion is closely related with a faster-closing canopy will shade the soil surface earlier, thereby reducing evaporation and increasing water availability for the crop, improving the crop water-use efficiency (Siddique et al., 1990). Also, the faster-expanding leaf canopy increases light interception more quickly (Richards, 2000), making the crop more competitive with weeds for light (Lemerle et al., 2001).

Limited information exists in the literature on growth and development of upland rice cultivars grown under Brazilian conditions. The objective of this study was to evaluate physiological traits of four contrasting parental upland rice cultivars to verify their adaptation to no-tillage system.

\section{MATERIALS AND METHODS}

A greenhouse experiment, with three different sowing dates, was conducted at the National Rice and Bean Research Center of EMBRAPA, Santo Antônio de Goiás, G0, Brazil during 2008 to evaluate phenological growth and development of upland rice cultivars. The soil used in the experiment was an Oxisol with chemical characteristics: $\mathrm{pH}$ in water 4.9, $\mathrm{Ca} 0.18$ $\mathrm{cmol}_{\mathrm{c}} \mathrm{dm}^{-3}, \mathrm{Mg} 0.11 \mathrm{cmol}_{\mathrm{c}} \mathrm{dm}^{-3}$, Al $0.2 \mathrm{cmol}_{\mathrm{c}} \mathrm{dm}^{-3}, \mathrm{H}+\mathrm{Al}$ $4.06 \mathrm{cmol}_{\mathrm{c}} \mathrm{dm}^{-3}, \mathrm{P} 0.6 \mathrm{mg} \mathrm{dm}^{-3}, \mathrm{~K} 12 \mathrm{mg} \mathrm{dm}^{-3}$, Cu $1.7 \mathrm{mg}$ $\mathrm{dm}^{-3}$, Zn $0.6 \mathrm{mg} \mathrm{dm}^{-3}$, Fe $34 \mathrm{mg} \mathrm{dm}^{-3}, \mathrm{Mn} 2 \mathrm{mg} \mathrm{dm}^{-3}$, and organic matter $12 \mathrm{~g} \mathrm{dm}^{-3}$. The experiment was conducted in plastic pots with $8 \mathrm{~kg}$ soil. Each pot received $12 \mathrm{~g}$ of dolomitic lime, $158 \mathrm{mg} \mathrm{K} \mathrm{kg}^{-1}, 69 \mathrm{mg} \mathrm{P} \mathrm{kg}^{-1}, 400 \mathrm{mg} \mathrm{N} \mathrm{kg}^{-1}, 20 \mathrm{mg}$ Zn kg-1, $5 \mathrm{mg} \mathrm{Cu} \mathrm{kg}^{-1}, 1 \mathrm{mg} \mathrm{B} \mathrm{kg}^{-1}$, and $0.5 \mathrm{mg} \mathrm{Mo} \mathrm{kg}^{-1}$ of soil. One third of $\mathrm{N}$ was applied at sowing and remaining was top dressed at two equal rates at the beginning of tillering, V4 stage of the Counce et al. (2000) scale, and at panicle differentiation (PD), R1 stage of Counce et al. (2000) scale. Four cultivated upland rice genotypes (BRS Primavera, BRS Curinga, BRS Soberana, and Douradão) were chosen due to their different morphological characteristics and are being used as parental lines in breeding programs. The sowing dates were $07 / 01 / 2008,27 / 08 / 2008$ and $17 / 10 / 2008$. Climatic data during the experiments periods are presented in Figure 1 . The 
experimental design was a completely randomized, with four replications.

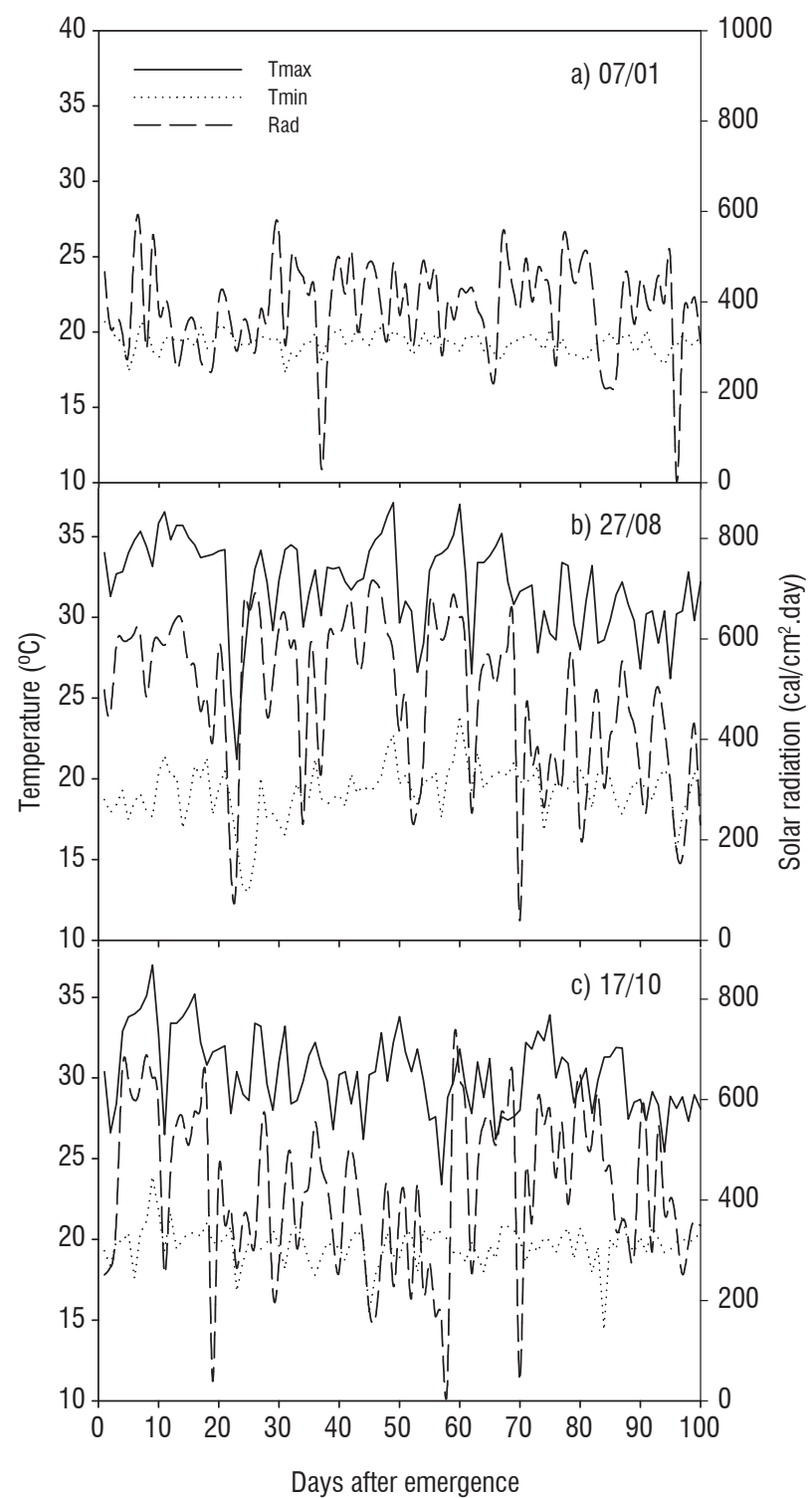

Figure 1. Climate variables maximum, minimum temperature and solar radiation to a) planting date $07 / 01$; b) planting date $27 / 08$ and c) planting date 17/10. Data obtained outside of the greenhouse, at a nearest weather station.

\section{Physiological Measurements}

Germination dates were recorded when $50 \%$ of the first coleoptile tip became visible. Panicle differentiation (PD) was identified by sampling plants (one plant for each replication) and cutting the main stem of these plants length wise, and a 2 $\mathrm{mm}$ long white and a fuzzy panicle similar to a small cotton ball was visible. Also heading and flowering dates were recorded for each genotype.

Individual leaf growth measurements were conducted on leaf of the main shoot for one plant per pot, on a first set of four plants per cultivar. Leaf length $(L)$ and width (W) were measured daily with a ruler in $\mathrm{cm}$ from the day they emerged from the sheath of a previous leaf until they were fully elongated. The main stem leaf numbers (LN) were also daily counted when the collar of the blade leaf was visible. The final leaf length (CF), in cm of individual leaves was calculated by fitting the leaf length $(\mathrm{L})$ versus days after emergence (DAE), using the following three parameters sigmoid function:

$$
L_{i}=\frac{C F}{\left(1+\exp \left(\left(b_{1}-D A E\right) / t h\right)\right)} \text { eq. } 1
$$

where, $b_{1}$ is when half of the leaf reached an inflexion point, in DAE, and th the time, between the inflexion point and the point where $b_{l} /\left(1+\mathrm{e}^{-1}\right) \cong 0,73^{\star} C F$, in DAE.

The leaf elongation rate (LER) was estimated by first order derivate from eq. 1, in $\mathrm{cm}$ day $^{-1}$, demonstrated by eq. 2 .

$$
f^{\prime}(x)=\frac{C F^{*} \exp \left(\left(\frac{b_{1}-x}{t h}\right) *\left(\frac{1}{t h}\right)\right)}{\left(1+\exp \left(\frac{b_{1}-x}{t h}\right)\right)^{2}} \mathrm{eq.} 2
$$

where $f^{\prime}(x)$ is the first order derivate of eq.1.

The leaf elongation duration (DUR, days) of individual leaves was calculated as the ratio between CF and LER.

Haun (1973) index (HI) was also calculated based on the following equation:

$$
H I=(L N-1)+L / C F
$$

Plants in each pot were cut at the base and the individual plant components were separated into leaves and stems. Leaf area was determined with a leaf area meter (LI 3000, LI-COR, $\mathrm{NE}$, USA). The plant parts, leaf and stem, were dried at $65^{\circ} \mathrm{C}$ for a constant weight. Total dry matter for plant was obtained by adding all plant components. 
For adjusting the no linear equation 1 and to calculate its derivate was used the statistical program $R$ ( $R$ Development Core Team, 2005), v. 2.72, package nlme.

\section{RESULTS AND DISCUSSION}

Plant development: Four cultivars showed different growth cycles and development (Figure 2). The longest duration cultivar was BRSMG Curinga, followed by BRS Primavera, Douradão and BRS Soberana. For cultivar BRSMG Curinga, the vegetative period (VP), from emergence to PD was having 53 to 56 days growth duration depending on planting dates. The PD was observed at full development of leaf 10 all planting dates. The difference in days of PD and the leaf 10 totally expanded was 6 for planting date $07 / 01,1$ for planting date of 27/08, and 2 for planting date 17/10 (Figure 2). The reproductive growth period (RP) which is defined as panicle differentiation to flowering (Fageria, 2007) varied from 26 to 32 days depending on date of planting. Planting date 27/08 had the longest RP duration (32 days). Flowering date ranged from 80 to $88 \mathrm{DAE}$, and the planting date $27 / 08$ was having the longest flowering period (88 DAE). For cultivar BRSMG Curinga, the main stem final leaf number (FLN) ranged from 12 to 13 and planting date 27/08 produced the highest FLN.

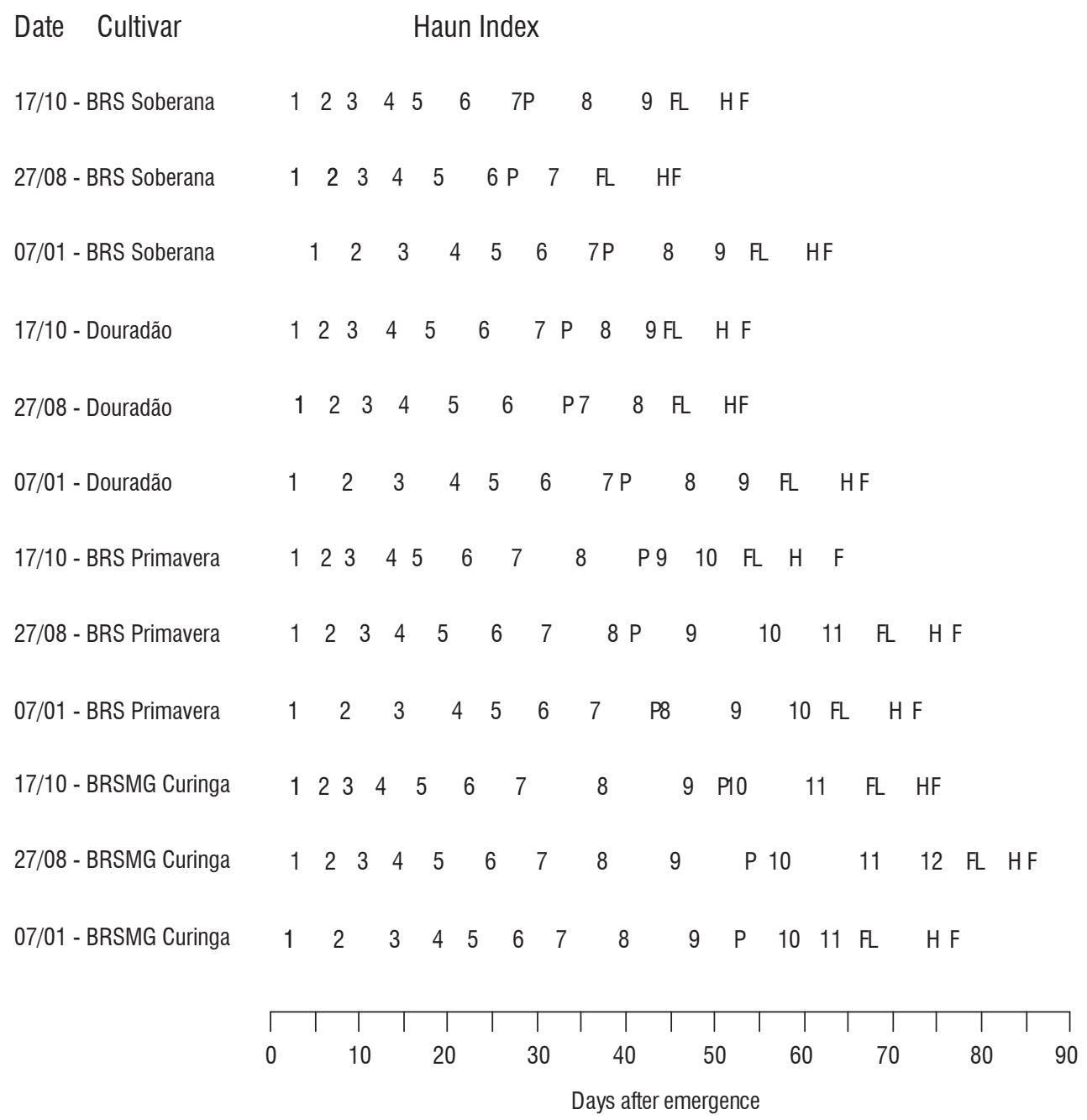

Figure 2. Haun Index for cultivars BRS Soberana, Douradão, BRS Primavera and BRS Curinga at three planting dates (7/01, 27/08 and 17/10). Numbers in the figure represents number of leaves expanded on the main stem. The $\mathrm{P}$ - panicle initiation, FL- flag leaf; $\mathrm{H}$ - heading and F- flowering. 
For cultivar BRS Primavera, the VP ranged from 43 to 45 DAE. The PD was initiated at the 9th leaf full developed for planting dates $27 / 08$ and $17 / 10$. However, for planting date $07 / 01$, the PD initiated at the 8th leaf full developed. The RP varied from 24 to 39 days. Planting date $27 / 08$ was having the longest RP growth period (39 days) and 17/10 planting date was having the shortest duration (24 days). Flowering date varied from 68 to 82 depending on date of planting. The FLN varied from 11 to 12 for cultivar BRS Primavera.

The cultivar Douradão, VP ranged from 35 to 40 DAE. The PD was initiated at the emergence of leaf 7 for planting dates $07 / 01$ and $27 / 08$. For planting date $17 / 10$, PD was initiated between emergence of leaves 7 and 8 . Hence, it is assumed that for this cultivar the PD initiation occurs when leaf 7 is totally expanded. The RP ranged from 20 to 29 days. The longest RP was observed for $07 / 01$ planting date for this cultivar. Flowering date varied from 55 to 69 DAE. For cultivar Douradão, the FLN ranged from 9 to 10 . As the opposite happened for the medium cycle cultivars, BRSMG Curinga and BRS Primavera as the planting date 27/08 showed the lowest value of FLN.

For cultivar BRS Soberana VP ranged from 29 to $38 \mathrm{DAE}$. The PD was initiated at the end of 7 th leaf full developed for planting dates $07 / 01$ and $17 / 10$. For planting date $27 / 08$, PD was initiated at the full development of 7 th leaf. The RP ranged from 20 to 27 days. The longest RP was observed for planting date $17 / 10$. Flowering date ranged from 49 to 65 DAE. For BRS Soberana, the FLN ranged from 8 to 10. As observed for cultivar Douradão, for cultivar BRS Soberana also planting date 27/08 showed the lowest value of FLN.

These results show that the number of developed leaves on the main stem until the PD as well as FLN are related with rice development cycle, which is affected by climatic conditions. Fageria (1992) reported that growth and development of annual crops is significantly affected by environmental conditions. Figure 3 show that FLN is correlated significantly with degree days accumulated from emergence to PD (Table 1). Similarly, FLN is also correlated with degree days accumulated from emergence to flowering (Figure 3b). Medium cycle cultivars, BRSMG Curinga and BRS Primavera, had higher FLN than short cycle cultivar BRS Soberana. Similar results were reported by Streck et al. (2006) with lowland rice cultivars.

The leaf number from $\mathrm{R} 1$ (PD) to flag leaf $(\mathrm{FL})$ ranged from 1.7 to 3.7 (Table 1). BRS Soberana, Douradão, BRS
Primavera and BRSMG Curinga showed an average of 2.6, 2.6, 3.0 and 2.6 leaves from R1 to FL, respectively. Similar results were reported by Yin and Kropff (1998). However, Freitas et al (2006) reported that $\mathrm{R} 1$ occurs when there are seven expanded leaves on main stem, which is in disagreement with the results obtained in this study. The number of leaves were highly correlated with accumulated degree-days from panicle differentiation to flowering (Figure 3c), indicating that the factors affecting the duration of this stage, as the growing cycle, were especially climatic conditions.

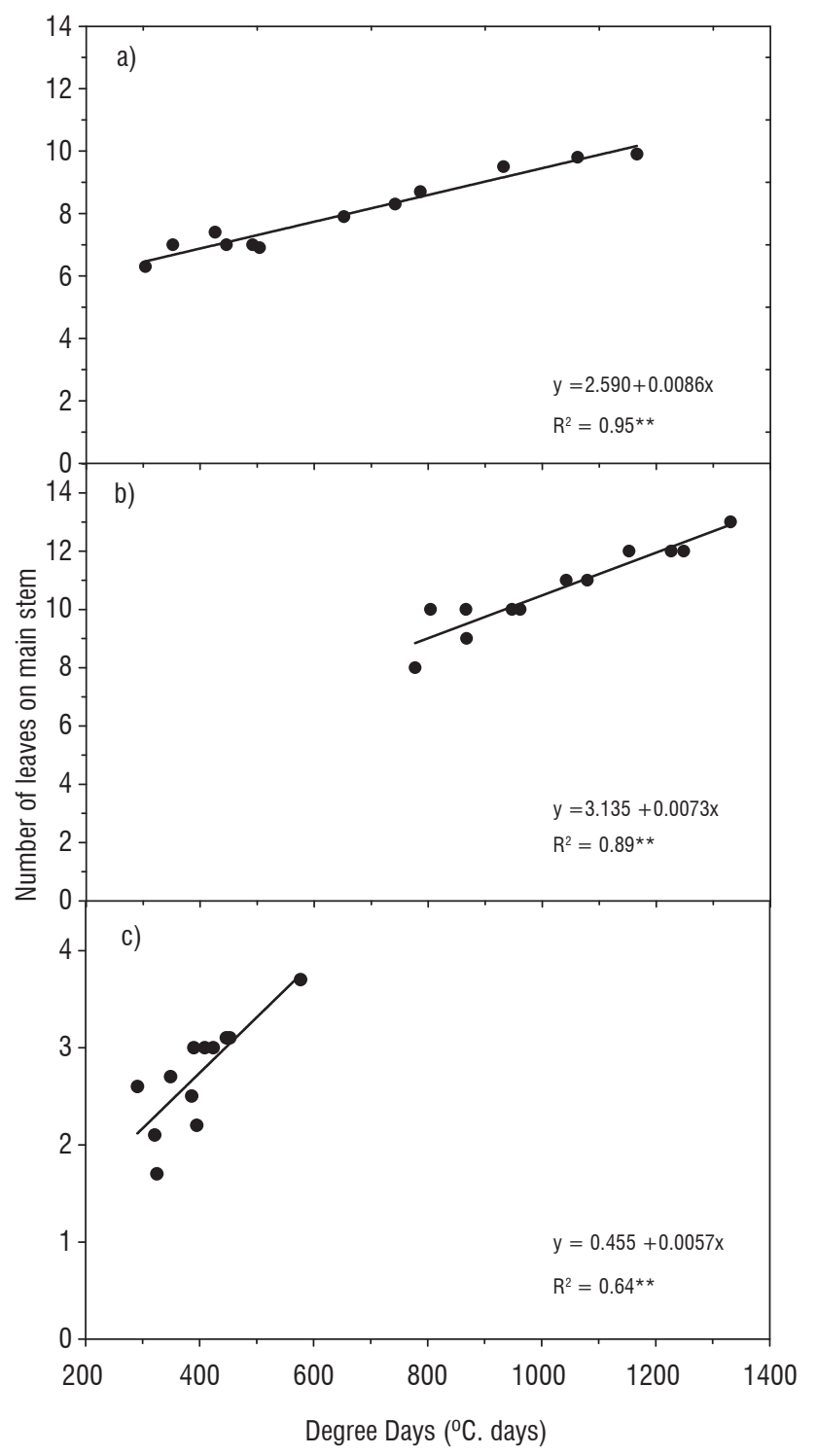

Figure 3. Relationship between degree days and number of leaves on the main stem (a) at panicle differentiation, (b) at flowering, and (c) from panicle differentiation to flowering. 
Table 1. Degree days from emergence to panicle differentiation (E-PD), panicle differentiation to flowering (PD-F), emergence to flowering (E-F) and the number of leaves on main stem from panicle differentiation to flowering (DP to F).

\begin{tabular}{|c|c|c|c|c|c|}
\hline Sowing date & Cultivar & ${ }^{\star} \mathrm{E}-\mathrm{PD}\left(\mathrm{C}^{0}\right.$.day $)$ & *PD-F (C․day) & ${ }^{\star} \mathrm{E}-\mathrm{F}$ (Co.day) & $\begin{array}{c}\text { Number of leaves from } \\
\text { DP to } F\end{array}$ \\
\hline $17 / 10$ & BRS Soberana & 476 & 390 & 866 & 3.0 \\
\hline $27 / 08$ & BRS Soberana & 452 & 325 & 777 & 1.7 \\
\hline $07 / 01$ & BRS Soberana & 523 & 424 & 947 & 3.0 \\
\hline $17 / 10$ & Douradão & 513 & 291 & 804 & 2.6 \\
\hline $27 / 08$ & Douradão & 546 & 321 & 867 & 2.1 \\
\hline $07 / 01$ & Douradão & 552 & 409 & 961 & 3.0 \\
\hline $17 / 10$ & BRS Primavera & 693 & 349 & 1042 & 2.3 \\
\hline $27 / 08$ & BRS Primavera & 671 & 577 & 1248 & 3.7 \\
\hline $07 / 01$ & BRS Primavera & 626 & 453 & 1079 & 3.1 \\
\hline $17 / 10$ & BRSMG Curinga & 831 & 395 & 1226 & 2.2 \\
\hline $27 / 08$ & BRSMG Curinga & 883 & 447 & 1330 & 3.1 \\
\hline $07 / 01$ & BRSMG Curinga & 766 & 386 & 1152 & 2.5 \\
\hline
\end{tabular}

*Maximum and minimum temperature obtained outside of the greenhouse; Base temperature $=10^{\circ} \mathrm{C}$.

Leaf Area and Biomass: Leaf area development, leaf and total dry matter production pattern were similar in four cultivars under three planting date (Figure 4). These parameters were increased in an exponential fashion with the advancement of plant age. The growth of four plants was slow up to 12 days after seedling emergence and then there was a linear increase. It maybe associated with increase in tillering and leaf number with the advancement of plant age. Fageria et al. (1982) and Fageria (2006) reported similar increase in dry matter and leaf area of upland rice with the advancement of plant age.

Leaf Expansion: The leaf length pattern of four cultivars was similar as a function of number of leaves on the main stem. The maximum leaf length (MLL) observed for planting date $7 / 01$ varied from 69.6 to $77.0 \mathrm{~cm}$. At the 07/01 sowing date cultivar Douradão showed the maximum leaf length value. The MLL was attained when there were 8 leaves on the main stem for cultivars Douradão, and BRS Soberana (Figure 5a). For cultivar BRS Primavera, the maximum leaf length was reached at the 9th leaf and for cultivar BRSMG Curinga maximum leaf length was reached at the 10 leaf on the main stem (Fig. 5a). There was a decrease in the leaf length after having 8 leaves on the main stem for cultivars Douradão and BRS Soberana. The decrease in leaf length for the cultivars BRS Primavera occurs at the 9th leaf and for the cultivar BRSMG at the 10th leaf on the main stem. Probably, the reason of this decrease is related with the beginning of $\mathrm{PD}$.

For planting date 27/08 (Figure $5 b$ ), the MLL ranged from 63.0 to $85.0 \mathrm{~cm}$. Cultivar BRS Primavera showed the highest leaf length value. At this planting date, only cultivar Douradão and BRSMG Curinga had the MLL at the antepenultimate leaf. Cultivar BRSMG Curinga and BRS Primavera had the MLL at the expanded leaf 9 on the main stem. For cultivar BRSMG Curinga, PD was observed between leaves 9 to 10 and for BRS Primavera between leaves 8 to 9 . Douradão had the MLL at the expanded leaf 8 on the main stem. The PD was observed at the end of leaf 7 development for cultivar Douradão. BRS Soberana showed the MLL at the expanded leaf 7 on the main stem. For this cultivar, PD was observed between leaves 6 to 7. For all cultivars the MLL was near the PD growth stage. It can be concluded that MLL is closely related to PD growth stage in upland rice cultivars for the planting date 28/08.

For planting date $17 / 10$ (Figure $5 c$ ), the MLL varied from 73.0 to $94.7 \mathrm{~cm}$. Again, cultivar BRS Primavera showed the highest leaf length value. At this planting date only Douradão had the MLL at the antepenultimate leaf. The BRSMG Curinga had the MLL at the leaf 11 expanded, which is different from the patterns observed under two other sowing dates. As showed in Figure $5 \mathrm{c}$, for this cultivar there was a reduction in leaf length between leaves 8 and 9 on the main stem. This may be related to some environmental stress because PD was observed at the 9 to 10 leaves on the main stem. Cultivar BRS Primavera had the MLL at the expanded leaf 8 and PD was between leaves 8 and 9 . Cultivar Douradão had the MLL at leaf 8 expanded and PD was observed between leaf 7 and 8 (Figure 2). BRS Soberana showed the MLL at the expanded leaf 7 and PD was observed between leaves 6 to 7 . Except 
for cultivar BRSMG Curinga, the MLL was near the PD growth stage.

Figure $5 d$, e and $f$ showed that the leaf elongation rate (LER) can be divided in two different phases for all planting dates. The first phase end when leaf 4 is totally expanded on the main stem. The LER is well defined for planting dates 07/01 and 27/08 (Figure 5e and f). For these planting dates the LER varied from 4.92 to $7.65 \mathrm{~cm} /$ day for all the cultivars. These results showed that there is not much difference among cultivars for LER. This may be associated with characteristic of upland rice cultivars to have lower values of LER at the growth stage. This phase occurs around 20 DAE and it is considerate a critical period in no-tillage system for competition with weeds. That is probably one reason that the breeding programs did no yet detected upland rice with higher early vigor. The next phase start at leaf 5 at the main stem and it is characterized by a faster increase on the LER, probably due to tillering, and after a decrease in LER. This decrease starts to be accentuated after PD growth satge. For planting date 17/10, cultivar BRSMG Curinga showed a different pattern of LER and this may happen probably due to the stress that plants might suffered during the growth.
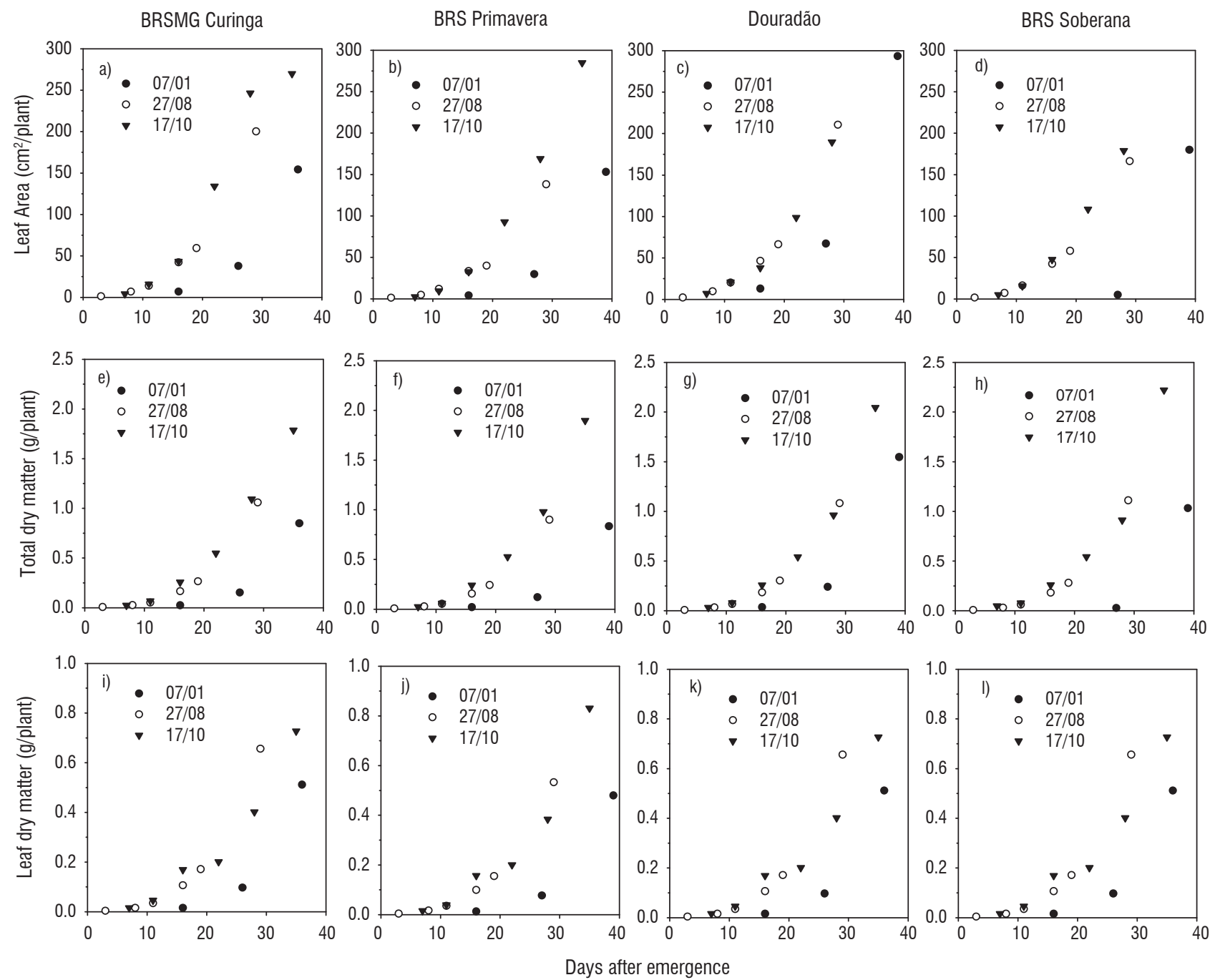

Figure 4. Leaf area, total dry matter and leaf dry matter for four cultivars at three sowing dates. 

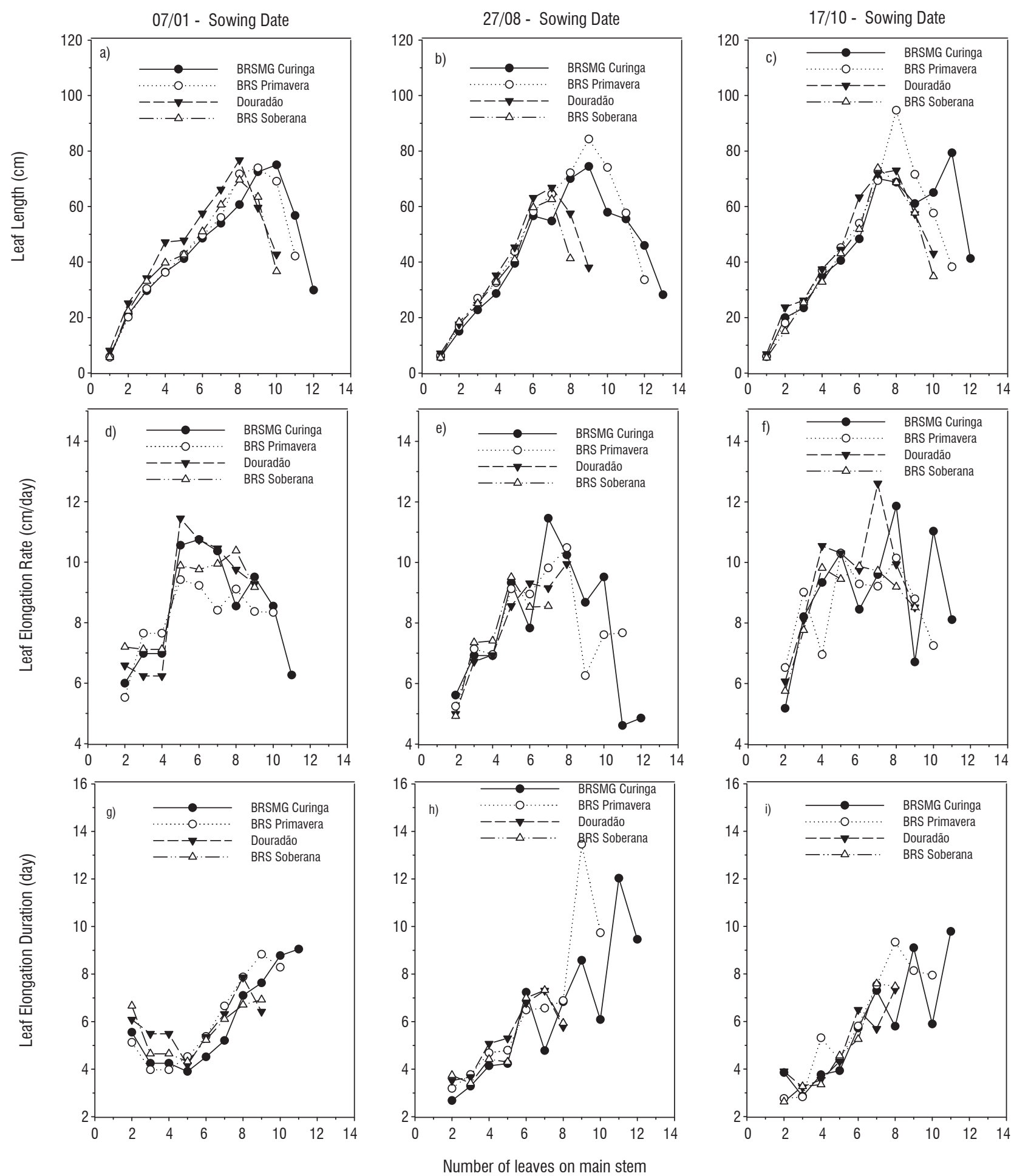

Figure 5. Relationship between number of leaves on the main stem and leaf length, leaf elongation rate (LER) and leaf elongation duration for four cultivars at three planting dates. 
Leaf elongation duration (LED) had a different pattern at planting date $07 / 01$ compared to planting dates $27 / 08$ and $17 / 10$. It started with high values and after the 2 leaf decreases and stabilizes until leaf 5 and then again increases. This different pattern of leaf elongation at this planting date may be associated with different climatic conditions. This planting period is characterized by rain and cloudy weather and temperature is also not very high. The other planting dates had an increase on the LED with the increase in leaf number at the main stem.

The four cultivars studied here were growth at potential condition. Based on the results, it was observed only differences in the development cycle, being BRSMG Curinga the latest and BRS Soberana the earliest cultivar. For the leaf area growth, biomass growth and the traits related to leaf expansion in the begin of the development (0 to 20 DAE or until 3 leaf totally expanded) it was not observed differences. Probably, the lack of genetic "early vigor" is a characteristic of modern cultivars, once that after 80s the upland breeding program was designed to generate knowledge and develop technologies targeting more favorable areas and taking into account mainly potential yield (Pinheiro, 2006). In spite of cultivar Douradão is considerate a traditional cultivar, it did also not show differences in the "early vigor" compared with modern cultivars (BRSMG Curinga, BRS Primavera and BRS Soberana). However, in this study there is not much evidence to affirm that the lack of genetic "early vigor" is specie characteristic. These four cultivars are used as parental lines and it can support the reason that the upland rice breeding program did not developed yet an upland rice cultivar with genetic "early vigor".

\section{CONCLUSIONS}

The knowledge of growth cycle of crop cultivars is an important issue in adopting appropriate management practices and improving yields. Additionally, knowledge of occurrence of growth stages can also be used in many physiological studies to identify the critical growth stage during plant growth that are sensitive to environmental factors, to take necessary measure to avoid stress and improve crop yields. The four upland rice cultivars evaluated in this study showed different growth duration. The dry matter and leaf expansion pattern, however, were similar in the four cultivars. The physiological traits related with leaf expansion were also similar probably being the lack of genetic "early vigor" a characteristic of the modern cultivars. In addition, the growth and development pattern and leaf expansion traits were significantly influenced by planting dates. Hence, it can be concluded that with the manipulation of planting dates, it is possible to avoid drought stress which occurs at a certain period in the cerrado region of Brazil, where upland rice is mostly cultivated. The short duration cultivars like BRS Soberana and Douradão may be better adapt to cropping systems under notillage or under water stress conditions compared to longer duration cultivars like BRS Primavera and BRSMG Curinga.

\section{REFERENCES}

Amado TJC, Bayer C, PC. Conceição, E Spagnollo, BC Campos, and M Veiga. (2006). Potential of carbon accumulation in zero tillage soils with intensive use and cover crops in southern Brazil. Journal of Environmental Quality 35:1599-1607.

Bolliger, AJ, Magid TJC, Amado FS. Neto, MFS Ribeiro, Calegari A., Ralisch R., and Neergaard A (2006). Taking stock of the Brazilian zero-till revolution: A review of landmark research and farmers practice. Advances in Agronomy 91:47-110.

Counce, PA., Keisling TC.; Mitchel, AJ (2000). A uniform, objective, and adaptative system for expressing rice development. Crop Science, 40: 436443.

Fageria, NK (2001). Nutrient management for improving upland rice productivity and sustainability. Communications in Soil Science and Plant Analysis 32;2603-2629.

Fageria, NK (2007). Yield physiology of rice. Journal of Plant Nutrition 30:843879.

Fageria, NK, and Baligar VC (2001). Improving nutrient use efficiency of annual crops in Brazilian acid soils for sustainable crop production. Communications in Soil Science and Plant Analysis 32:1303-1319.

Fageria, NK, and Baligar VC. (2003). Fertility management of tropical acid soils for sustainable crop production. In: Handbook of soil acidity, ed. Z Rengel, 359-385. New York: Marcel Dekker.

Fageria, NK., Baligar VC, and Clark RB (2006). Physiology of crop production. New York: The Haworth Press.

Fageria, NK, MP Barbosa Filho, and Carvalho JRP (1982). Response of upland rice to phosphorus fertilization on a Oxisol. Agronomy Journal 74:51-56.

Freitas, TFS, Silva PRF, Strieder LM, A.A Silva (2006). Validation of the development scale for Brazilian flooded rice cultivars. Ciência Rural, v.36, n.2, p.404-410.

Haun JR (1973). Visual quantification of wheat development. Agronomy Journal, 65:116-119.

Instituto Brasileiro Geográfico Estatístico (IBGE). Levantamento Sistemático da Produção Agrícola. 2006. (http://www.sidra.ibge.gov.br/bda/)

Lemerle D, Gill GS, Murphy CE, Walker SR, Cousens RD, Mokhtari S, Peltzer SJ, Coleman R, Luchett DJ (2001). Genetic improvement and agronomy for enhanced wheat competitiveness with weeds. Australian Journal of Agricultural Research. 52:527-548.

Pinheiro B da S, Castro E da M de, Guimarães CM (2006) Sustainability and profitability of aerobic rice production in Brazil. Field Crops Res 97:34-42

Moura Neto, FP, Soares AA, Aidar H. (2002). Performance of cultivars of high land rice under no-tillage and conventional systems. Ciência e Agrotecnologia, $26,5,904-910$ 
R Development Core Team (2005) R: A language and environment for statistical computing. R Foundation for Statistical Computing, Vienna, Austria. ISBN 3-900051-07-0, URL http://www.R-project.org.

Reis, MS, Soares AA, Cornélio VMO., Soares PC, Guedes JM., Costa Júnior GT (2007). Behavior of upland rice genotypes under no-tillage and conventional tillage. Pesquisa Agropecuária Tropical, 37, 4, 227-232.

Richards R.A. (2000). Selectable traits to increase crop photosynthesis and yield of grain crops, J. Exp. Bot., 51: 447-458.

Siddique, KHM, Tennat D, Perry MW, Belford RK (1990). Water use and water use efficiency of old and modern wheat cultivars in a mediterranean-type environment. Australian Journal of Agricultural Research. 41:431-447.
Streck NA, Bosco LC, Michelon S, Walter, LC, Marcolin, E. (2006) Duration of developmental cycle of rice cultivars as a function of main stem leaf appearance. Ciência Rural., 36, 4, 1086-1093.

Trethowan, RM., Reynolds M. (2005). Drought resistance: genetic approaches for improving productivity under stress. In: Proceedings of the 7th international wheat conference, 27 November-2 December 2005, Mar del Plata, Argentina.

Yin X, Kropff MJ (1998) The effect of the photoperiod on interval between panicle initiation and flowering in rice. Field Crop Research, 57: 301-307. 